Please cite this paper as follows:

Akbar, S., Shafiq, R., Liu, J. and Shah, SZA (2017). Credit supply constraints and financial policies of listed companies during the 2007-2009 financial crisis. Research in International Business and Finance, DOI: https://doi.org/10.1016/j.ribaf.2017.07.001.

Weblink: http://www.sciencedirect.com/science/article/pii/S0275531916304330

(C) 2018. This manuscript version is made available under the CC-BY-NC-ND 4.0 license http://creativecommons.org/licenses/by-nc-nd/4.0/ 


\title{
Credit supply constraints and financial policies of listed companies during the 2007- 2009 financial crisis
}

\begin{abstract}
This study examines the effects of lending constraints on the financial policies of UK publicly listed companies during the 2007-2009 financial crisis. Using a sample of 2039 publicly listed firms, the results of our analysis indicate that financial policies of firms are sensitive to variations in the supply of external finance and credit, suggesting that liquidityconstraint firms with low cash reserves suffered more at the time of the credit crunch. While managing through the potential negative effects of the financial crisis, majority of the sample companies increased the use of internal finance and deferred the payments of dividends which helped them apply effective financial policies during the crisis period. The findings of this study also document that during the crisis period, financial policies of firms were exposed to variations in the supply of finance and credit, which, by implication, posed a threat to their operations, sustainability and growth. Our findings produce awareness about the negative effects of the non-availability of external finance and credit supply to listed companies, and signify the role of different financing channels and credit system in the operations and growth of listed companies. These findings have implications for financial regulation and policy making in the UK.
\end{abstract}

Keywords: Financial crisis, financial policies, financial management, total debt, trade credit, credit crunch

JEL Classification: G01, G32 


\section{Introduction}

The 2007-2009 financial crisis is widely recognized as the most severe global economic downturn since the Great Depression (see for example, Mian and Sufi, 2009; Melvin and Taylor, 2009; Frederic, 2011; Obstfeld, 2012). The crisis originated from the US in 2007 and has affected markets and institutions at the core of the financial system around the world (see for example, Majid and Kassim, 2009; Brzoza-Brzezina and Mikulski, 2011; Mala and Chand, 2012; Jones et al., 2012; Flannery et al., 2013). In the United Kingdom, the effect of the financial crisis became evident in the aftermath of an increased number of defaults in the financial sector, such as, Northern Rock, Bradford and Bingley, Alliance and Leicester, HBOS and a number of other building societies (Hall, 2008; Hall, 2009).

The increased number of defaults has raised awareness concerning risk management on the part of financial institutions. As a result, financial institutions have become more cautious and are taking various measures for reducing risk in their lending activities. Predominantly banks have tightened lending through imposing more complex terms and conditions. This raises the concern that disruptions in lending may have caused significant shocks to the supply of credit, which militate against the corporate investment and operational undertakings (Nanda and Nicholas, 2013). Thus the depth and scale of the potential impacts of the financial crisis on the corporate sector have helped engender a growing body of research with a particular reference to the effects of the financial crisis (see for example, Saleem, 2009; Leary, 2009; Lemmon and Roberts 2010; Lin and Paravisini, 2013; Mac an Bhaird, 2013; Yarovaya and Lau, 2016; Cevik, Dibooglu and Kenc, 2016; Jiang, 2017) .

In this regard, Lemmon and Roberts (2010) investigate the shocks to the junk bond market caused by regulation changes and the collapse of Drexel Burnham Lambert in 1990s, and the subsequent effects on the leverage and investment decisions of firms which borrowed from that market. Their results indicate that aggregate external financing activities were squeezed, and the financing and investment decisions of below investment grade firms were affected as a result of financial crisis of that time. Similarly, Voutsinas and Werner (2011), Carey et al. 2012, Forsberg 2012, show that the capital structure of firms is sensitive to variations in the supply of credit. However, Campello, Giambona, Graham and Harvey (2012) indicate that the average size of available credit lines did not change during the crisis period in Europe. All these findings thus present mixed and inconclusive evidence on this issue.

While recognizing existing literature's substantial contribution, we submit that material 
shortcomings remain. Firstly, these relate most notably to unduly limited examination of capital structure in response to credit shocks. The existing literature has not adequately explored the role of individual components of capital structure and as a result the findings are not able to fully identify which component of capital structure is more sensitive to credit supply contractions as compared to another. Secondly, existing studies on financial crisis are predominantly based on the US market. However, it has been recognized by the existing literature that there are institutional differences in terms of culture, insolvency code, tax system, accounting regulation and ownership structure between the US and other economies of the world (see for example, Franks and Torous, 1996; Dahya and Travlos, 2000; Beattie, Goodacre and Thomson, 2006; Akbar, Shah and Stark, 2011). Investigating the financial policies of publicly listed firms during the 2007-2009 financial crisis with data from the UK economic system is therefore expected to provide new insights.

It is therefore evident from the above discussions that due to institutional and cultural differences between the US and other countries, the applicability of research findings from US data is limited to other economies. It is thus argued that the impact of variations in the supply of credit on the financial policies of firms outside the US needs examination. Accordingly, we carry out this investigation for the generation of new evidence on this issue by employing a sample of UK publicly listed companies. We consider the UK for this investigation because UK has one of the largest stock markets outside of the US, which provides a different institutional setting and regulations. In addition, despite the severe implications of the current financial crisis on the UK economy there is still little evidence available on these issues in the UK. We therefore address the following research questions in this paper.

1. Is there any effect of credit supply contractions on the financial policies of public firms in the United Kingdom?

2. How does shock to the supply of credit affect the leverage ratios of publicly listed firms in the United Kingdom?

3. Which component of capital structure is affected the most by the credit supply contractions?

4. Does publicly listed firms in the United Kingdom switched to alternative sources of finance during the period of credit supply contractions?

Keeping the above questions in mind and in order to investigate the contemporary effect of the financial crisis on the financial policies of UK public firms this study uses a sample of 2039 publicly listed firms over the period between 2004 and 2009. We take a closer look at 
the impact of the financial crisis on the capital structure by making a detailed analyses of the debt components and other sources of finance with a view to identify the channels through which the supply shock travels. Our empirical strategy enables us to identify how publicly listed firms minimized the effect of credit contractions by resorting to alternative sources of finance such as internal funds, net debt issue, trade credit and net equity issue. In particular, it helped us gain enhanced understanding of the extent of substitution across credit sources. This would also help clarify how public firms manage their finances during the crisis period.

However, investigating the effect of credit supply shocks on firms' financing behaviour poses identification problems because we need to separate the supply effect from the endogenous demand effect. We have tried to cover this problem from three different perspectives. First, we cover the identification of exogenous variations in the supply of credit from the pre-crisis to the crisis periods. Second, we adopt firm fixed effects models to control interdependence among variables. As our study is using panel data set, there is a potential concern of unobserved heterogeneity, however, fixed effect regression models account for this problem, because such models have the advantage that it accounts for both observable and unobservable firm characteristics and heterogeneity (Bougheas, Mizen and Yalcin 2006; Mateut, Bougheas and Mizen, 2006; Gan, 2007; Xiaolou, 2011). Third, to account for demand side factors, this study includes firm level variables, which are used as proxy for firm demand.

The results show that financial crisis has negatively affected the total debt ratio of publicly listed firms. The results further highlight that financial crisis has heterogeneously influenced the components of firms' financial structure, whose effects are transmitted through the trade credit channel rather than the short term and long-term financing channels. We conclude that financial policies of publicly listed firms are sensitive to variations in the supply of credit during the course of the financial crisis. The practical potential of this study in terms of policy making is thus to inform the decision makers of the monetary authorities about their attitude in corporate lending. This is more important at a time like the present when continuity and sustainability is uncertain and is subject to the effect of global instability.

The rest of the paper is organized as follows. Section 2 presents a review of previous literature which contains discussions on both current and classical studies. Section 3 discusses methodology and data. This section provides details of the empirical strategy by highlighting theoretical background of the models, and description of the data collection process, measurement of variables, and model specification and econometric issues. Section 4 
highlights results from the estimation of all models where detailed commentary is provided and the outcome is matched with the existing literature. Finally, section 5 concludes the paper by presenting a short summary of the study and by citing some limitations and avenues for future research.

\section{Review of Literature}

\subsection{Theoretical Developments}

Theoretical developments covering the capital structure of firms originates from Modigiliani and Miller (1958), who argue that in a perfect capital market, in the absence of transaction costs and taxes, the market value of a firms is depending upon its earning power and risk of underlying assets, and is independent from capital structure. However, Modigiliani and Miller (1963) incorporate tax advantage as a potential determinant of capital structure and argue that firms can maximize their value by employing more debt in their capital structure because of the tax shield advantage associated with the use of debt and that firms can maximise their value by employing more debt in their capital structure. In another seminal paper, Miller (1977) argues that in a world where interest payments are tax deductible the value of the firm still remain independent from its capital structure.

Over the years several theoretical papers have covered the notion of optimal capital structure, such as agency theory (Jensen and Meckling 1976), signalling theory (Ross 1977), the bankruptcy cost theory (Titman 1984), and the pecking order theory (Myers 1984; Myers and Majluf 1984). Most of these and other relevant theories have relaxed the assumptions of perfect capital market and provided evidence that, in an imperfect capital market, firms' financing does affect their value, suggesting that firms' financing decisions matter in an imperfect capital market. Jensen (1986) argues that debt financing reduces the conflict of interest between managers and shareholders. Those theories which are based on information asymmetry suggest that information imbalance plays a significant important role in determining firms' optimal capital structure (Bharath, Pasquariello and Wu 2009). In this regard, Gatchev, Spindt and Tarhan (2009) highlight that information asymmetry and agency cost play a significant role in the firms' financing decisions.

Ardalan (2008) however, regards the mainstream published academic literature in finance as mainly focusing upon the functionalist paradigm which according to the arguments raised in this study, the classical finance theories do not consider. He argues that the application of 
other theoretical approaches in finance is beneficial for enhancing our understanding about the nature of issues covered in finance research. Similarly, Ardalan (2017) regards the assumption about the capital structure irrelevance of firms as unrealistic and argue that as the result of financial models in the mainstream finance literature are based on certain assumptions, a change in those assumptions will make the findings questionable. He argues that the objective of a firm is share price maximisations, and as debt as a source of finance contain risk, the capital structure cannot be irrelevant and that there is an optimal capital structure for firms.

In relation to understanding the causes of the recent financial crisis, Lawson (2009) regard existing theoretical frameworks used by current research papers as an insufficient and asks for the establishment of a more grounded theoretical framework for the understanding the crisis. Considering the limitation of existing theoretical literature (see for example, Modigiliani and Miller 1958, 1963, amongst others), and the arguments raised about the methodological limitations of the mainstream finance research (see for example, Ardalan 2008; Lagoarde-Segot 2016; Ardalan 2017, amongst others), use of a more refined framework will be beneficial for understanding the causes and implications of the crisis. In line with these arguments this study constructs a model where a firm's capital structure is a function of both demand and supply side factors. It is therefore expected that the outcome of our results will provide new insights in this area of research which will help us better understand the causes and implications of the 2007-2009 financial crisis. An overview of existing literature in this area is presented in sub-section 2.2 and 2.3 below.

\subsection{Credit Supply Contractions and Firms' Financing Mix}

There is abundance of theoretical and empirical literature which suggests that the financing mix of large publicly listed firms is not sensitive to variations in the supply of bank credit. In addition, due to the prevailing financial reporting regulations, information in the financial statements of publicly traded firms is generally regarded as reliable and true. As a result listed firms have easier access to wider channels for raising funds, such as, public market, commercial paper market, etc. (see for example, Blinder and Stiglitz, 1983; Gertler and Gilchrist, 1993; Reinhart and Rogoff, 2011). Even in a tightening monetary situation, the flow of bank credit and non-bank debt to larger firms increases (Gertler and Gilchrist, 1993; Frank and Goyal, 2009; Acharya and Rangarajan, 2011 ). Similar findings are also reported by, Oliner and Rudebusch (1995), Kashyap and Stein (2000), and Berger, Miller, Petersen, 
Rajan and Jeremy (2005) who argue that the proportion of debt including bank and non-bank debt as well as trade debt in the capital structure of larger public firms expanded during the monetary contraction period.

Several studies have examined banks' lending behaviour in the tight monetary period and confirmed that bank loans were decreased to financially-constrained firms whereas to the non-financially-constrained firms the amount of loans increased (Gertler and Gilchrist, 1994;Oliner and Rudebusch, 1995; Bernanke, Gertler and Gilchrist, 1996; Oliner and Rudebusch, 1996). Similarly, findings of Gertler and Gilchrist (1993) suggest that bank lending to larger public firms are not much affected following stringent monetary policy. While investigating the impact of the current financial crisis on large public firms, Iyer et al. (2010) argue that the 2007-2009 financial crisis did not significantly disturb the credit flow to large firms.

The overall findings of the above-mentioned papers thus suggest that credit contractions have not significantly affected the financing mix of large listed firms. These findings are also in line with the argument that listed firms maintain long track records, better diversification, economies of scale in generating and reporting information and low agency cost of external finance (Bernanke, Gertler and Gilchrist, 1996; Clarke et al. 2012; Cull and Martinez Paeris, 2013). In addition, information asymmetry and idiosyncratic risk are likely to be low in these firms and as a result, these firms raise funds from a number of external sources of finance such as; issuing debt, equity and commercial papers in the open market (Gertler and Gilchrist, 1993; Gertler and Gilchrist, 1994; Holmstrom and Tirole, 1997; Stein, 2003). Even they could also avail the opportunity of reallocating their loans demand within the banking system (Bruno, 2009). It has also been reported in the literature that banks only consider safer loan options during tight credit conditions (see for example, Lang and Nakamura, 1995).

In contrast to the foregoing, Lemmon and Roberts (2010) demonstrate that large public firms are vulnerable to the credit supply shocks. They find a significant impact of the exogenous shocks to credit supply on the financing decisions of below investment-grade firms and observe more reduction of external finance for such firms following shocks to the supply of credit. They also report that a reduction in the supply of credit is mostly concentrated in the net long term debt issuance category. They argue that although the supply of credit contractions affects the financing activities of below investment-grade firms, their effect on the leverage ratio is negligible. Similarly, Gambacota, and Marques-Ibanez (2011) highlight that banks with weaker capital positions restricted the provision of loans during the crisis period. 
In a related context, Lin and Paravisini (2013) examine how credit shocks affect firm financial and investment policies. They take the bankruptcy of the WorldCom in 2002 as a natural experiment to investigate whether the WorldCom events exert the heterogeneous effect on the US banks supply of credit, which, in turn, influence firms' external cost of debt financing. They find that banks which participated in syndicate loans to the WorldCom firms reduced the supply of credit to those firms more than the non-participating banks during the post crisis period. The reduction was found stronger on bank-dependent firms as compared to other firms. Among the bank-dependent firms, those firms whose main lenders were exposed to the WorldCom events face increased costs of raising further bank finance due to the adverse selection problem. Similarly, Voutsinas and Werner (2011) and Saretto and Tookes (2013), show that the capital structure of firms is sensitive to variations in the supply of credit.

After summarising findings of the above mentioned studies we argue that the overall evidence is mixed and inconclusive. It is not clear from findings of the existing studies as to which components of financing mix are more sensitive to variations in the supply of credit as compared to others. This specifies gaps in the existing literature which need further investigations. We now discuss the behaviour of firms with respect to alternative sources of finance in the next section.

\subsection{Credit Supply Contractions and Alternative Sources of Finance}

Some of the latest research findings document that when the supply of external credit squeezes, firms' substitute to alternative sources of finance in the form of internal finance, debt (bond debt), trade credit and equity finance (Leary, 2009; Campello et al. 2011; Lin and Paravisini, 2012). These alternative sources of finance serve as a buffer to alleviate credit constraints due to the credit supply shocks (Kashyap, Lamont and Stein, 1994; Bae, Kang and Lim, 2002; Leary, 2009) . In addition, findings of a survey conducted by Graham and Harvey (2001) suggest that practitioners view 'Financial Flexibility' as an important factor in deciding about the sources of finance to use.

One of the techniques of maintaining financial flexibility is the use of internal finance. In this regard, the importance of internal finance is evidenced in the Myers (2001) seminal report which highlights that, 'Most of the aggregate gross investment by US nonfinancial corporations has been financed from internal cash flow (depreciation and retained earnings)'. Similarly, Acharya, Almeida and Campello (2013) document that at times of 
higher risk, gaining credit is costly for firms and as result they opt to use internally generated cash for their finances. Likewise, most of the previous studies on capital structure show that internal finance is an important determinant of firms' financing decision (see for example, Jordan, Lowe and Taylor, 1998; Ozkan, 2001; Frank and Goyal, 2003; Panno, 2003). These studies suggest that firms tend to rely more on internal finance, should they face restricted access to external finance.

With respect to bond finance, it is also documented in some recent research findings that large public firms substitute to bond finance when bank finance is squeezed. In this regard, the findings of Judge and Korzhenitskaya (2012) suggest that large firms are more likely to immune themselves by resorting to bond finance when they face restricted access to bank finance. Their other analyses are based on the sub-sample of leverage and credit rating, which reveals that the effect of bank loan supply is pronounced on high leveraged and speculative grade firms.

On the issue of equity as an alternative source of finance, Kahle and Stulz (2013) and Lin and Paravisini (2012 ) note that firms are more likely to substitute to equity finance and hold more cash following negative shocks to bank credit. They regard an increase in a firm's equity issue as an indication towards a decline in the firm's leverage and argue that that cash holding of firms' increase immediately after the credit supply shocks which they maintain for two years after the shock. This finding is consistent with the precautionary saving motive which would help firms during and after the period of credit contractions.

Some empirical studies, however, do not support the notion that firms would resort to alternative sources of finance when the supply of credit squeezes. In this regard, Campello et al. (2011) and Lemmon and Roberts (2010) find limited evidence regarding firms' substitution towards alternative sources of finance such as internal finance, short term debt, trade credit, equity, and change in dividends pay-out following shocks to the supply of credit. Similarly, Judge and Korzhenitskaya (2012) and Leary (2009) find that firms, which have access to public debt market, are less likely to use alternative sources of finance following the credit crunch and argues that large firms substitute from private to public debt during tight monetary conditions.

On the basis of the above discussions we argue that the role of alternative sources of finance during the period of shocks to the supply of credit is not clear from the existing findings. Moreover, findings of the existing studies do not fully distinguish the sources of finance which are sensitive to the credit supply shocks from those which are not. In light of this argument and by considering the lack of consensus among the findings of the published 
literature in this area a re-examination of this issue is worth doing. In order to meet our research objectives and to conduct a detailed investigation of all related issues we discuss our research methodology and data in the section 3 below.

\section{Methodology and Data}

\subsection{Methodology}

In order to investigate the effect of credit supply shocks on the financial policies of UK public firms we first consider the Modigliani and Miller (1958) hypothesis of a firm's capital structure as a function of various demand side factors as the first step in our methodology. In line with this hypothesis, many existing studies have modelled a firm's financing mix as a function of firm characteristics with respect to size, age and growth as well as its financial status with respect to profitability, risk, asset tangibility and liquidity (see for example, Ozkan, 2001; Cassar and Holmes, 2003; Daskalakis and Psillaki, 2008; Akbar, Rehman and Ormrod, 2013). In a functional form this can be expressed as follows.

$\mathrm{CS}=f($ size, age, growth, profitability, risk, asset tangibility, liquidity)

A firm's capital structure function is constructed on the basis of an implicit assumption that the supply of capital is frictionless, and accordingly any firm can finance all valueenhancing projects. However, new findings about capital market imperfections in recent years have challenged the Modigliani and Miller's (1958) perfect capital market hypotheses and document that the financing of firms depend on both demand and supply factors (see for example, Sufi 2009; Choi, Getmansky, Henderson and Tookes 2010; Lemmon and Roberts 2010). Similarly, Ardalan (2008, 2017), and Lagoarde-Segot (2016) regard the theoretical assumptions about the capital structure irrelevance of firms as unrealistic because a change in those assumptions is making the research findings questionable, and asks for the application of other theoretical approaches. Lawson (2009) suggests that existing theoretical frameworks used by current research papers for understanding the causes of financial crisis are insufficient and asks for the establishment of a more grounded framework for the 
understanding the crisis. We therefore construct a model where a firm's capital structure is a function of both demand and supply side factors as follows.

$\mathrm{CS}=\gamma_{0}+\gamma_{1} \mathrm{D}+\gamma_{2} \mathrm{~S}+\varepsilon_{\mathrm{it}}$

Where, D stands for demand shocks and $\mathrm{S}$ stands for supply shocks. On estimating the effect of credit supply shocks on firms' financing, changes in capital structure due the financial crisis may simply reflect the unobserved shift in firms' demand for capital (Duchin, Ozbas and Sensoy, 2010; Puri, Rocholl and Steffen, 2011). We therefore separate the effect of supply shocks from the demand effect by a three-step identification strategy. First, as the crisis has negatively affected both the supply and demand of credit we identify external variations in the supply of credit and recognise the effect of credit supply shocks on the capital structure of firms during the recent fincial crisis. Second, in order to overcome the problem of unobserved heterogeneity in panel data, we have adopted firm fixed effects models, because it produces unbiased and consistent coefficient estimates (Jeon and Miller, 2004). Third, a set of control variables have been used for isolating the effect of demand factors, which include, return on assets and growth and their interaction with the crisis dummy as a proxy for firms' demand ${ }^{1}$. These steps not only permit us to identify the supply effects but also help us in separating the pre-crisis effects from the crisis effects (see for example, Gan, 2007; Love, Preve and Sarria-Allende, 2007; Sufi, 2009; Chava and Purnanandam, 2011; Akbar, Rehman and Ormrod, 2013, amongst others).

To capture the change from pre-crisis to the crisis period, we extend model (b) by incorporating interactive terms between the dummy variable representing the financial crisis and demand and supply variables. The matrix representation of simultaneous equation models is expressed below.

$C S_{i t}=\gamma_{0}+\gamma_{1} * D_{i t}+\gamma_{2} *$ Crisis $+\gamma_{3} * D_{i t} *$ Crisis $+\varepsilon_{i t}$

Where, $\mathrm{CS}_{\mathrm{it}}$ is a vector representing firms' leverage ratios; $\mathrm{D}_{\mathrm{it}}$ is a matrix of firm-level control variables representing the demand side factors; Crisis is a dummy variable which is equal to 1 for the period 2007-2009, and 0 otherwise for the period 2004-2006; $\gamma_{1}$ is the coefficient matrix capturing the effect of demand side factors; $\gamma_{2}$ is the coefficient matrix

\footnotetext{
${ }^{1}$ In the trade credit model we use cash flows and growth and their interaction with the crisis dummy as the control variables.
} 
capturing the credit supply shock effect by identifying the extent to which firms' financial structure is affected by the financial crisis, $\gamma_{3}$ is the coefficient matrix of the interactive terms measuring the change in demand factors during the crisis period relative to the pre-crisis period.

Model (c) is the benchmark model for the total debt ratio which is regressed on both the demand and supply side factors. We further decompose total debt into long term debt, short term debt and trade credit. The three components of the debt structure are then entered into the equations as the dependent variables and as a result the following equations are formed.

Long term debt $=\gamma_{0}+\gamma_{11} * \mathrm{ROA}+\gamma_{12} * \mathrm{GT}+\gamma_{2} * \mathrm{CR}+\gamma_{31} * \mathrm{GT} * \mathrm{CR}+\gamma_{32} * \mathrm{ROA} * \mathrm{CR}+\varepsilon_{\mathrm{it}}$
Short term debt $=\gamma_{0}+\gamma_{11} * \mathrm{ROA}+\gamma_{12} * \mathrm{GT}+\gamma_{2} * \mathrm{CR}+\gamma_{31} * \mathrm{GT} * \mathrm{CR}+\gamma_{32} * \mathrm{ROA} * \mathrm{CR}+\varepsilon_{\mathrm{it}}$
Trade Credit $=\gamma_{0}+\gamma_{11} * \mathrm{CF}+\gamma_{12} * \mathrm{GT}+\gamma_{2} * \mathrm{CR}+\gamma_{31} * \mathrm{GT} * \mathrm{CR}+\gamma_{32} * \mathrm{CF} * \mathrm{CR}+\varepsilon_{\mathrm{it}}$

Next, we extend model (c) by taking account of net debt issue, net equity issue, cash reserves and dividends which are regressed on the control variables and the supply side dummy. The resulting equations are reported as follows.

$$
\begin{aligned}
& \text { Net Debt Issue }=\gamma_{0}+\gamma_{11} * \mathrm{ROA}+\gamma_{12} * \mathrm{GT}+\gamma_{2} * \mathrm{CR}+\gamma_{31} * \mathrm{GT} * \mathrm{CR}+\gamma_{32} * \mathrm{ROA} * \mathrm{CR}+\varepsilon_{\mathrm{it}} \\
& \begin{array}{ll}
\text { Net Equity Issue } & =\gamma_{0}+\gamma_{11} * \mathrm{ROA}+\gamma_{12} * \mathrm{GT}+\gamma_{2} * \mathrm{CR}+\gamma_{31} * \mathrm{GT} * \mathrm{CR}+\gamma_{32} * \mathrm{ROA} * \mathrm{CR}+\varepsilon_{\mathrm{it}} \\
\text { Cash Reserves } & =\gamma_{0}+\gamma_{11} * \mathrm{CF}+\gamma_{12} * \mathrm{GT}+\gamma_{2} * \mathrm{CR}+\gamma_{31} * \mathrm{GT} * \mathrm{CR}+\gamma_{32} * \mathrm{CF} * \mathrm{CR}+\varepsilon_{\mathrm{it}} \\
\text { Dividends } & =\gamma_{0}+\gamma_{11} * \mathrm{ROA}+\gamma_{12} * \mathrm{GT}+\gamma_{2} * \mathrm{CR}+\gamma_{31} * \mathrm{GT} * \mathrm{CR}+\gamma_{32} * \mathrm{ROA} * \mathrm{CR}+\varepsilon_{\mathrm{it}}
\end{array}
\end{aligned}
$$

\subsection{Variables}

Total debt (CS) includes all interest bearing and capitalized lease obligations and is measured as the sum of short term debt, long term debt and trade credit, divided by total assets. Long term debt is measured as all interest bearing financial obligations, excluding those amounts which are due for payment within one year, divided by total assets. Short-term debt includes bank overdraft, notes payable and the current portion of long term debt due for payment within one year, divided by total assets. Trade credit is taken as the measure of trade credit during the year, divided by total assets. Return on assets (ROA) is measured as earnings 
before interest and tax, divided by total assets. Growth (GT) is measured as sales in year t divided by sales in year t-1. Net equity issue is measured as the change in issued capital divided by start of the period issued capital. Net debt issue is measured as the change in the sum of short term debt and long term debt divided by the sum of the start of period short term debt plus long term debt. Cash flow (CF) is measured as cash flows from operating activities, divided by total assets. Cash reserves are measured as change in cash and cash equivalent divided by the start of the period cash and cash equivalent. Dividends is measured as change in dividends in year t divided by last year's dividends. Net trade credit is measured as accounts receivable less accounts payable, divided by total assets.

\subsection{Data and Sample}

The study sample initially contained all UK listed companies over the period 2004-2009, where all data was extracted from Datastream. However, due to various reasons we removed some firms from our final sample. First, all those firms whose market value was not reported in UK Pound Sterling were excluded from the sample. Second, financial firms were excluded from the sample for standard reasons. Third, following previous literature, utility companies, such as electricity, gas and telephone were excluded from the sample (Brav, 2009; Duchin, Ozbas and Sensoy, 2010; Chava and Purnanandam, 2011; Lin and Paravisini, 2012). Fourth, unquoted firms and firms missing data for the main variables of the study were excluded from the final sample. We also adjusted the data for outliers by winsorizing the top and bottom $1 \%$ of observations for all variables. The final sample thus includes 2039 listed UK companies.

\subsection{Model Specification and Econometric Issues}

We carried out the Hausman (1978) model specification test to compare the outcome of fixed and random effects models on the assumption that the outcome of both models will be similar. The model specification test results confirmed that the outcome of the two sets of estimations as different. We then compared the two sets of results and confirmed the use of fixed effects models as an appropriate method for this investigation over and above the 
random effects models. We also considered other econometric issues such as; multicollinearity and heteroscedasticity in the data. First, for taking care of multicollinearity, simple correlations among variables were calculated. It has been argued in the existing literature that a high correlation value would indicate a sign of multicollinearity (Aivazian, Ge and Qiu, 2005). As a result, we carefully checked all the correlations among the variables and confirmed the presence of no high correlation among the variables. We also take account of the issue of heteroscedasticity in the data by applying White (1980) consistent standard errors estimates. The t-statistics reported in Tables 1-3 are based on robust standard errors estimates, based on White (1980).

\section{Results and Discussions}

\subsection{Financial crisis and the debt structure of public firms}

While examining the effect of the credit crisis on the leverage ratios of public firms, we take two steps. In the first stage, we run the fixed effects regression model on total debt ratio and then in the second stage we run the regression models on short term debt, long term debt and trade credit separately. This analytical strategy permits us to identify the channel through which supply shocks travel and furthers our understanding of how firms switch across credit sources. 
Table 1

Effect of Financial Crisis on Leverage Ratio

\begin{tabular}{|c|c|c|c|c|}
\hline Variables & $\begin{array}{c}\text { Model c } \\
\text { Total Debt }\end{array}$ & $\begin{array}{l}\text { Model d } \\
\text { Long term } \\
\text { debt }\end{array}$ & $\begin{array}{l}\text { Model e } \\
\text { Short term } \\
\text { debt }\end{array}$ & $\begin{array}{c}\text { Model f } \\
\text { Trade credit }\end{array}$ \\
\hline ROA & $\begin{array}{c}-0.126 * * * \\
(-3.99)\end{array}$ & $\begin{array}{l}-0.002 \\
(-0.26)\end{array}$ & $\begin{array}{c}-0.038 * * * \\
(-3.58)\end{array}$ & ------ \\
\hline GT & $\begin{array}{c}0.0002 \\
(0.14)\end{array}$ & $\begin{array}{c}-0.002 * * \\
(-2.01)\end{array}$ & $\begin{array}{l}0.002 \\
(1.04)\end{array}$ & $\begin{array}{l}0.001 \\
(0.84)\end{array}$ \\
\hline $\mathrm{CF}$ & & & & $\begin{array}{c}-0.023 * * * \\
(-2.41)\end{array}$ \\
\hline $\mathrm{CR} * \mathrm{ROA}$ & $\begin{array}{l}-0.002 \\
(-0.05)\end{array}$ & $\begin{array}{c}-0.024 * * * \\
(-2.63)\end{array}$ & $\begin{array}{l}-0.001 \\
(-0.05)\end{array}$ & ------ \\
\hline $\mathrm{GT}^{*} \mathrm{CR}$ & $\begin{array}{c}0.009 * * * \\
(2.77)\end{array}$ & $\begin{array}{c}0.004 * * * \\
(2.63)\end{array}$ & $\begin{array}{l}-0.001 \\
(-0.20)\end{array}$ & $\begin{array}{l}0.002 \\
(1.21)\end{array}$ \\
\hline $\mathrm{CF}^{*} \mathrm{CR}$ & & & & $\begin{array}{c}-0.027 * * * \\
(-2.84)\end{array}$ \\
\hline $\mathrm{CR}$ & $\begin{array}{c}-0.013 * * \\
(-2.32)\end{array}$ & $\begin{array}{l}-0.001 \\
(-0.31)\end{array}$ & $\begin{array}{c}0.004 \\
(0.958)\end{array}$ & $\begin{array}{c}-0.007 * * * \\
(-3.17)\end{array}$ \\
\hline $\mathrm{C}$ & $\begin{array}{c}0.288 * * * \\
(80.72)\end{array}$ & $\begin{array}{c}0.111 * * * \\
(75.93)\end{array}$ & $\begin{array}{c}0.055 * * * \\
(21.61)\end{array}$ & $\begin{array}{c}0.114 * * * \\
(87.83)\end{array}$ \\
\hline R-squared & 0.731 & 0.820 & 0.594 & 0.815 \\
\hline F-statistics & 9.014 & 11.59 & 4.85 & 14.61 \\
\hline Prob(F-statistics) & 0.000 & 0.000 & 0.000 & 0.000 \\
\hline No of Obs & 7546 & 5602 & 7492 & 7441 \\
\hline
\end{tabular}

Notes: Where CR represents the crisis dummy, CF represents cash flows from operations, GT stands for sales growth, and ROA specify return on assets. During the crisis period the effect on dependent variable is calculated by adding the coefficients of the given variable and variable interacted with the crisis dummy. Furthermore, in order to calculate the change in response relative to the pre-crisis and crisis period and the net-response during the crisis period the crisis dummy is interacted with control variables we have added the coefficients. In addition, the pre-crisis period is represented by the non-interacted variable coefficients. Also, $* * *, * *, *$ specify $1 \%, 5 \%$ and $10 \%$ levels of significance respectively.

Table 1 presents results from the estimation of model (c-f). The results show that the signs of all the independent variables are according to expectations. Return on assets (ROA) has a significant, negative association with capital structure in the pre-crisis period. We may assume that a higher ROA would mean a higher cash flow in the sample firms and the outcome is thus consistent with the pecking order theory which suggests that the availability of internal funds reduces firm's reliance on external finance. The coefficient on ROA interacted with the crisis dummy variable is negative but statistically insignificant. It is interesting to note that ROA is not significant in the crisis period. The insignificance may suggest that public firms are making financing decisions irrespective of their financial performance during the crisis period. These results are in line with Deesomsak, Paudyal and 
Pescetto (2004) who find that the sign and significance of profitability vary in leverage regressions between the post and pre-crisis period. However, other studies are inconclusive on the effect of profitability on firms' financing decisions (see for example, Franks, Nyborg and Torous, 1996; Krishnan and Moyer, 1997; Fattouh, Scaramozzino and Harris, 2005; Garlappi and Yan, 2011).

The results further show that the coefficient on the growth variable is positive in both the pre- and post-crisis periods. It is however, significant only in the crisis period. This suggests that during the period of economic diversity firms in need of external finance are those which have insufficient internal funds for financing their growth. This finding is consistent with findings of some of the previous literature (see for example, Titman and Wessels, 1988; Krishnan and Moyer, 1997; Michaelas, Chittenden and Poutziouris, 1999). However, the finding is in contrast to some of the earlier studies (see for example, Barclay and Smith, 1995; Rajan and Zingales, 1995; Ozkan, 2001; Antoniou, Guney and Paudyal, 2008; Leary, 2009). The lack of significance of the growth variable in the pre-crisis period supports the argument that growth does not play a significant role in the financing decisions of firms during a normal time period.

The results also show that the coefficient on the crisis dummy is negative and significant at the $5 \%$ level. The negative effect on total debt ratio is evidenced to the effect that the credit crisis has squeezed the flow of credit to these firms. Since total debt encompasses all forms of debt, including short term debt, long term debt and trade credit, we can plausibly argue that aggregate external financing activities of public firms reduced in response to the exogenous credit crisis. In this regard, Lemmon and Roberts (2010) find a consistent result for firms with below investment grades. By contrast, our results disagree with the findings of Lin and Paravisini (2012) which suggest that credit contractions have no effects on total debt ratio. Similarly, Campello et al. (2012) find that the average line of credit did not change during the crisis period.

The results of model (c) do not reveal which component of total debt ratio is affected by the credit supply shock. To gain understanding of how individual components of debt structure respond to the credit supply shocks, we ran separate regressions on long term debt, short term debt and trade credit as in equations (d)-(f). In so doing, we are able to quantify the effect of substitution across the different credit sources. We also focused on the effect of the financial crisis with a view to identify which channels are affected the most by the recent panic in the financial markets. 
The fixed effects regression for model (d) is run on long term debt. The results in column 2 of Table 1, show that coefficient on the crisis dummy variable is negative, but statistically insignificant. As a result, robust conclusion cannot be drawn from these findings. The lack of significance may imply that the crisis has not affected the long term financing channel of public firms. This result seems to be inconsistent with the findings reported in Lemmon and Roberts (2010). They find that supply contractions have negatively affected the long term net debt issuance of the below-investment-grade firms.

Next, we focus on the short term financing channel. The panel fixed effects regression for model (e) is run on short term debt. Results from the estimation of model (e) are presented in column 3 of Table 1, which suggest that the coefficient on the crisis dummy variable is positive, but statistically insignificant at the conventional level. The results also suggest that the crisis has no significant impact on the short term financing channel. In other words, the flow of short term credit to large firms is not significantly affected by the recent credit retrenchments.

Finally, the fixed effects regression is run on trade credit as in model (f). The results in column 4 of Table 1, show that majority of the control variables are significant with a high Rsquare value. Most notably, the coefficient of the crisis dummy is negative and significant at the $1 \%$ level. This suggests that the flow of trade credit to public firms is reduced during the crisis period. These results are thus parallel to the findings of Kohler, Britton and Yates (2000). They examined the trade credit behaviour of the UK quoted firms in a monetary tightening conditions, and find that quoted firms received less trade credit during the recession period. However, our results are in contrast to Petersen and Rajan (1997), Biais and Gollier (1997), Nilsen (2002), and Ge and Qiu (2007) who report that firms increase the use of trade credit when the supply of credit squeeze. Overall, we argue that that the flow of trade credit is sensitive to the credit supply shocks in times of financial crisis.

The results also suggest that the coefficient of cash flow interacted with the crisis dummy is negative (-0.02) and significant at the $1 \%$ level. This finding indicates that internally generated funds negatively affect the firm's demand for external credit (trade credit) during the crisis period. This is consistent with the pecking order theory, i.e., the more internally generated fund is available, the less a firm needs external finance (trade credit). This finding implies that internal fund is an important alternative to trade credit. This finding is consistent with previous literature (see for example, Atanasova and Wilson, 2003; Franks and Goyal, 2003; Atanasova and Wilson, 2004; Love, Preve and Sarria-Allende, 2007).

In addition, our results suggest the lack of substitution towards the source of short term 
finance. The reduction in short term finance implies that public firms do not hedge themselves from the effect of credit supply contractions by resorting to trade credit. This may be because of the availability of other creditable channels available to these firms for raising funds such as, issuing equity, public debt and commercial papers in open markets (Gertler and Gilchrist, 1994). Overall, our results suggest that during the crisis period the flow of trade credit was negatively affected due to which public firms reduce the use of short term debt during the financial crisis.

To sum up all the above discussions, we argue that the financial crisis has adversely affected the total debt ratio of public firms. Our investigation of the individual components of debt structure reveals that the adverse impact of the financial crisis works through the trade credit channel instead of the short term and long term financing channels. Our study contributes to the existing literature by first demonstrating that both the demand and supply factors are integral parts of the firm's financing decisions. Second, trade credit in the case of listed firms is sensitive to credit contractions. Third, trade credit does not compensate for a reduction in the supply of credit from financial institutions. In the next section, we focus on the effect of credit supply shocks on firms' behaviour about the use of alternative sources of finance.

\subsection{The Use of Alternative Sources of Finance}

We first examine firms' behaviour of substituting to alternative sources of finance for offsetting the reduction in the level of debt in their capital structure. The alternative sources of finance in this study refer to net debt issued, net equity issued, internal finance and dividends. The fixed effects panel regression is run separately on each of these variables as defined by Equations $(\mathrm{g})-(\mathrm{j})$, for which the results are presented in Table 2. Model $(\mathrm{g})$ presents the regression results on net debt issued. The coefficient of the crisis dummy is 0.50 and is weakly significant, suggesting that net debt issue of public firms was reduced during the crisis period. This result is consistent with our earlier findings that contractions in credit supply have negatively affected the total leverage ratio of public firms.

Model (h) presents the regression results on net equity issued. It appears that the crisis exerts a significant negative impact on net equity issued by public firms. This is a clear indication that public firms issue less equity during the crisis period. This result suggests that during the crisis period when the market underperforms, management of firms hold back by not issuing new equity. We can plausibly argue that equity finance is not a substitute to other 
sources of finance in the market downturn. These results are in line with some of the existing studies, for instance, Lemmon and Roberts (2010) which find limited evidence of substitution towards equity finance in addition to short term debt and trade credit. Our result, however, appears in contrast with that of Leary (2009) and Lin and Paravisini (2013) which suggest that firms substitute to equity finance when credit becomes difficult to obtain from the financial market.

Table 2

Financial Crisis and Firms' Substitution to Alternative Sources of Finance

\begin{tabular}{|c|c|c|c|c|}
\hline Variables & $\begin{array}{l}\text { Model g } \\
\text { Net Debt } \\
\text { Issue }\end{array}$ & $\begin{array}{l}\text { Model h } \\
\text { Net Equity } \\
\text { Issue }\end{array}$ & $\begin{array}{c}\text { Model i } \\
\text { Cash Reserve }\end{array}$ & $\begin{array}{c}\text { Model j } \\
\text { Dividends }\end{array}$ \\
\hline ROA & $\begin{array}{l}0.019 \\
(0.04)\end{array}$ & $\begin{array}{l}-0.806 \\
(-0.88)\end{array}$ & ------- & $\begin{array}{c}1.382 \\
(11.59)\end{array}$ \\
\hline GT & $\begin{array}{l}-0.012 \\
(-0.17)\end{array}$ & $\begin{array}{c}-1.054 * * \\
(-2.06)\end{array}$ & $\begin{array}{l}0.168^{*} \\
(1.81)\end{array}$ & $\begin{array}{c}0.401 \\
(5.65)^{* * *}\end{array}$ \\
\hline $\mathrm{CF}$ & & & $\begin{array}{r}1.911 * * * \\
(2.34)\end{array}$ & \\
\hline $\mathrm{ROA} * \mathrm{CR}$ & $\begin{array}{l}-0.076 \\
(-0.10)\end{array}$ & $\begin{array}{c}1.783 * * * \\
(2.90)\end{array}$ & ------ & $\begin{array}{c}0.589 * * * \\
(4.029)\end{array}$ \\
\hline $\mathrm{GT}^{*} \mathrm{CR}$ & $\begin{array}{c}0.500 * * \\
(1.99)\end{array}$ & $\begin{array}{c}0.886 * * * \\
(2.37)\end{array}$ & $\begin{array}{l}-0.166 \\
(-1.22)\end{array}$ & $\begin{array}{l}0.036 \\
(0.35)\end{array}$ \\
\hline $\mathrm{CF}^{*} \mathrm{CR}$ & & & $\begin{array}{c}2.323 * * \\
(2.28)\end{array}$ & \\
\hline $\mathrm{CR}$ & $\begin{array}{c}-0.505^{*} \\
(-1.67)\end{array}$ & $\begin{array}{c}-2.154 * * * \\
(-3.50)\end{array}$ & $\begin{array}{c}-0.902 * * * \\
(-3.98)\end{array}$ & $\begin{array}{l}-0.252 * * \\
(-2.305)\end{array}$ \\
\hline $\mathrm{C}$ & $\begin{array}{l}-0.026 \\
(-0.61)\end{array}$ & $\begin{array}{c}2.544 * * * \\
(3.01)\end{array}$ & $\begin{array}{c}1.796 * * \\
(13.35)\end{array}$ & $\begin{array}{c}-3.999 * * * \\
(-5.328)\end{array}$ \\
\hline R-squared & 0.274 & 0.357 & 0.318 & 0.529 \\
\hline F-statistics & 1.085 & 1.326 & 1.452 & 2.503 \\
\hline Prob(F-statistics) & 0.024 & 0.000 & 0.000 & 0.000 \\
\hline No of Obs & 5953 & 5156 & 7113 & 2271 \\
\hline
\end{tabular}

Notes: Where CR represents the crisis dummy, CF represents cash flows from operations, GT stands for sales growth, and ROA specify return on assets. During the crisis period the effect on dependent variable is calculated by adding the coefficients of the given variable and variable interacted with the crisis dummy. Furthermore, in order to calculate the change in response relative to the pre-crisis and crisis period and the net-response during the crisis period the crisis dummy is interacted with control variables we have added the coefficients. In addition, the pre-crisis period is represented by the non-interacted variable coefficients. Also, $* * *, * *, *$ specify $1 \%, 5 \%$ and $10 \%$ levels of significance respectively. 
We next examine the change in cash and cash equivalent and consider whether firms increase the use of internal finance or hold cash during the crisis period. The results from the estimation of model (i) are reported in column 3 of Table 2 . We find a highly significant and negative impact of the crisis dummy on cash and cash equivalent. This is consistent with the expectations that firms reduce cash reserve during the crisis period. The reduction of cash reserve suggests the possibility that public listed firms increase the use of internal funds to finance the existing or essential operational and investment activities to counter the adverse effect of credit supply contractions.

In addition, the coefficient of cash flow interacted with crisis dummy is positive and significant at the level of $5 \%$. This suggests that in order to cope with adverse credit conditions during the crisis period, firms that generate positive internal cash flows kept higher cash reserves. In addition, our results show that the interaction term of growth with the crisis dummy is positive and highly significant at the $1 \%$ level. This result confirms our earlier finding that firms with growth prospects need more external finance during the crisis period when credit supply squeezes. This finding is also consistent with previous findings in this area of research (see for example, Chen, 2004; Colombo, 2001).

Our results are, in part, consistent with previously published studies in this area. For example, Leary (2009) argues that firms uses all forms of alternative financing including internal finance when they face restricted access to credit. Similarly, Campello et al. (2010) conduct a survey of chief financial officials and conclude that firms burn more cash during the crisis period. However, our results are in contrast with Lemmon and Roberts (2010) who finds limited evidence on substitution among alternative sources of finance including the use of internal finance. Overall our findings suggest that the pecking order hypothesis is also applicable to the corporate financing behaviour of public firms during the financial crisis period.

This study further examines whether listed firms adjust their dividends pay-out policy during the crisis period. It is generally agreed that when obtaining external credit becomes difficult, firms scale back shareholder distributions to maintain their cash positions and spending on other essential operational and investment activities. The fixed effects regression model ( $\mathrm{j}$ ) is thus run on change in dividends. The crisis dummy appears to be significant and negatively associated with the change in dividends. This is consistent with the expectation that public firms adjust their dividends policies by means of reducing dividends pay-out to retain their financial slack in the economic downturn. This finding also is consistent with those of Campello, Graham and Harvey (2010) who argue that firms have deeper cut on 
dividends distributions during the recent crisis period. By contrast, Lemmon and Roberts (2010) find that firms with below investment-grade rating do not dip into cash reserve nor reduce dividends pay-out to counter the possible adverse effects of the crisis. Our result provides evidence complementing the above studies by suggesting that dividends pay-out of public firms is sensitive to the credit market conditions.

In addition, we have also classified the sample firms into liquidity-constraint group and liquidity-unconstraint groups on the basis of their average pre-crisis liquidity position. In line with previous literature in this area, we used cash and cash equivalent as a measure of liquidity (see for example, Duchin et al. 2010; Love et al. 2007). First, we identified all those firms in the sample whose cash and cash equivalent as a fraction of total assets was less than or equal to the sample mean and classified it as the liquidity-constraint group. Second, we formed another group of firms whose average cash and cash equivalent figure as a fraction of total assets was greater than the sample mean and classified it as liquidity unconstraint firms.

In this regard, earlier studies suggest that firms, which have greater ex ante liquidity, are less exposed to the financial shocks (see for example, Love et al. 2007; Campello et al. 2009a; Duchin et al. 2010; Denis, 2011). Similarly, Gao and Yun (2009) find supportive evidence to the effect that the financial crisis of 2008 has a more pronounced impact on the performance of firms with low liquidity compared to those with high liquidity prior to the crisis. We hypothesize that firms with high cash reserve prior to the crisis are in a better position to cushion themselves from the negative credit supply shocks. To test this prediction, we run separate regressions on the two groups using the fixed effects regression. The results reported in Table 3, highlight that financial crisis has adversely affected the total debt ratio of liquidity-constraint firms; however, its effect on the unconstraint firms is statistically insignificant which reveal that liquidity-constraint firms are hit harder by the financial crisis in comparison to unconstraint firms. These findings are consistent with the existing literature concerning the credit supply effect. 
Table 3

\begin{tabular}{lcc|} 
The Effect of Financial Crisis on Liquidity Constraint and Unconstraint Firms \\
\hline Variables & $\begin{array}{c}\text { Constraint Firms } \\
\text { Total debt }\end{array}$ & $\begin{array}{c}\text { Unconstraint Firms } \\
\text { Total debt }\end{array}$ \\
ROA & $-0.109^{* * *}$ & $-0.088^{* * *}$ \\
& $(-2.407)$ & $(-2.55)$ \\
GT & 0.002 & 0.003 \\
& $(1.428)$ & $(1.10)$ \\
ROA*CR & 0.003 & 0.010 \\
& $(0.087)$ & $(0.32)$ \\
GT*CR & 0.012 & 0.004 \\
& $(1.344)$ & $(0.93)$ \\
CR & $-0.019 *$ & 0.003 \\
& $(-1.650)$ & $(0.38)$ \\
C & $0.340^{* * *}$ & $0.162 * * *$ \\
& $(92.072)$ & $(20.67)$ \\
R-squared & 0.648 & 0.565 \\
F-statistics & 6.644 & 4.649 \\
Prob(F-statistics) & 0.000 & 0.000 \\
No of Obs & 1116 & 2808 \\
\hline
\end{tabular}

Notes: Where CR represents the crisis dummy, GT stands for sales growth, and ROA specify return on assets. During the crisis period the effect on dependent variable is calculated by adding the coefficients of the given variable and variable interacted with the crisis dummy. Furthermore, in order to calculate the change in response relative to the pre-crisis and crisis period and the net-response during the crisis period the crisis dummy is interacted with control variables we have added the coefficients. In addition, the pre-crisis period is represented by the non-interacted variable coefficients. Also, ***, $* *, *$ specify $1 \%, 5 \%$ and $10 \%$ levels of significance respectively.

In addition, as a robustness check we removed all those firms from the sample which have a direct exposure to the subprime crisis, such as real estate firms, and re-run all the regressions. This enabled us to minimize any demand side factors which would otherwise affect our results (Chava and Purnanandam, 2011; Lin and Paravisini, 2012). The revised results are qualitatively similar to those reported in the above tables. We therefore argue that the results of this study which are drawn from the estimation of our models are not driven by the demand side factors ${ }^{2}$. The robustness check also strengthens the claims that we put forward in relation to the findings and implications of this research.

In summary, our results appear to have identified that the financial crisis has adversely affected the total debt ratio of publicly listed firms. The results further reveal that financial crisis works through the trade credit channel instead of the short term and long term debt channels. In order to counter the adverse effect of the financial crisis, public firms increase the use of internal finance and scale back dividends payments which is consistent with it being part of the initiative for preserving their financial slack. The sample firms, however, do not substitute to the external sources of finance including net debt issue, equity finance and

\footnotetext{
${ }^{2}$ In order to preserve space we do not report results of the robustness check analysis in the paper.
} 
trade credit in the market downturn. In addition, the crisis has hit liquidity constraint firms much harder than the liquidity unconstraint firms. We therefore stress on the need for using effective financial management techniques by all firms in stable as well as adverse credit conditions. This is in line with Mac an Bhaird (2013) who argues that during the crisis period effective financial management techniques are specifically beneficial for those firms which heavily rely on external financing in their operations because these firms are fully exposed to the negative effects of the crisis.

\section{Conclusion}

This study examines the contemporary effect of the financial crisis on the financial policies of UK publicly listed firms and assesses its impacts on the individual components of the debt structure. We adopt firm fixed effects model as our empirical strategy for this investigation. Using a sample of 2039 UK public firms over the period 2004-2009, we find that credit supply shocks have adversely affected the total debt ratio of publicly listed firms. In addition, our results also suggest that the credit supply contractions have impaired the trade credit channel of public firms. In contrast, there is little evidence to suggest that the financial crisis had an impact on the short term and long term debt financing channels of public firms.

The outcome of our findings thus suggests, that in order to counter the adverse effect of credit contractions, public firms increased the use of internal finance and adjusted their dividend policy by deferring the payment of dividends to shareholders. We however, did not find any evidence in relation to public firms' substitution to the use of net debt issue, net equity issue and/or trade credit during the financial crisis period. In addition, our results also reveal that liquidity-constraint firms with lower cash reserves prior to the crisis suffered more during tight lending conditions. As a robustness check all the regression models were reestimated without the inclusion of firms which has direct exposure to the credit crisis (such as real estate firms). The results remained qualitatively similar to those reported in the paper suggesting that our results are not driven by the demand side factors. Our overall findings thus appear to suggest that the financial policies of public firms are exposed to variations in the supply of credit in the course of the financial crisis, which, by implication, may pose a threat to their operations, sustainability and growth in the future.

In light of the evidence presented in this study, we argue the findings of this study have several implications. First, our evidence describes and explains the benefits of applying 
effective financing policies by public firms, which helped them, manage their financing needs well during difficult times. This finding has implications for all publicly listed firms, suggesting that liquidity-constraint firms can use different financing channels for effectively managing the negative effects of financial crisis. Second, in terms of successfully managing the liquidity-constraint firms' financial position we argue that management of these companies should apply effective financial management policies in stable business environments, which will be beneficial to them in preparing more effectively for managing their finances well during difficult economic conditions. Third, our findings document the impact and implications of non-availability of external finance on the operations, sustainability and growth of public companies. As publicly listed companies play a significant role in the sustainability and growth of our economy and society, we argue that the findings of this research have implications for future financial regulation and policy making in the UK.

This study explored the effects of the financial crisis on firms' financial policies on the basis of annual panel data. However, a number of studies have suggested that quarterly data can best capture subtle changes of the time series between the shorter periods (see for example, Duchin, Ozbas and Sensoy, 2010; Chava and Purnandam, 2011; Murfin, 2012). However, due to the non-availability of quarterly data for the main variables of this study, we regard the use of quarterly data beyond the scope of this paper. The application of quarterly data in relation to investigating the effects of financial crisis on the financial policies of UK public firms is therefore left to future research. Moreover, the influences which we analyse in this paper can be pursued into the role of relationship lending on the financing policies of firms during the crisis period. Evidence in the existing literature suggests that during the crisis period, maintaining a long term relationship with lenders would enable firms to pay lower interest rates and offer little or no collateral for receiving loans (Boot and Thakor, 1994; Ioannidov and Ongena, 2010). An examination of the role of relationship lending during the financial crisis period would be worth investigating in future research.

In addition, as highlighted by Lawson (2009) existing theoretical frameworks used by current research papers are insufficient for explaining the cases of the crisis. In line with this, as the research models of this paper are based on certain assumptions which may influence the results of the paper, concrete conclusions cannot be drawn from these results. The use of alternative methodologies are therefore expected to produce new insights in this area. As this research covers an important aspect of our society, the application of social theory that covers different key paradigms about the nature of social science and society as a whole will be 
beneficial (Burrel and Morgan 1979). The use of triangulation method in future research is therefore expected to help in enhancing our understanding of the issues covered in this paper (see Downward, 2016). We therefore argue that for producing an in-depth understanding of the causes of the financial crisis a more sophisticated framework containing the application theoretical approaches from other disciplines will be beneficial.

\section{References}

Acharya, Viral V., Heitor Almeida, and Mmrillo Campello. 2013. Aggregate Risk and the Choice between Cash and Lines of Credit. The Journal of Finance 68(5): 2059-2116. Acharya, Viral, Rangarajan K. Sundaram, Kose John. 2011. Cross Country Variations in Capital Structures: The Role of Bankruptcy Codes. Journal of Financial Intermediation 20(1), 25-54.

Aivazian, Varouj A., Ge Ying, and Qiu Jiaping. 2005. The Impact of Leverage on Firm Investment: Canadian Evidence. Journal of Corporate Finance 11(1-2): 277-291.

Akbar, Saeed, Shafiq Rehman, and Phillip Ormrod. 2013. The Impact of Recent Financial Shocks on the Financing and Investment Policies of UK Private Firms. International Review of Financial Analysis 26(1): 59-70.

Akbar, Saeed, Syed Z. A. Shah, and Andrew W. Stark 2011. The Value Relevance of Cash Flows, Current Accruals, and Non-Current Accruals in the UK. International Review of Financial Analysis 20(5): 311-319.

Ardalan, K., 2008. On the Role of Paradigms in Finance, Aldershot, Hampshire, U.K., and Burlington, Vermont, USA: Ashgate Publishing Company.

Ardalan, K. 2017. Capital structure theory: Reconsidered. Research in International Business and Finance 39, 696-710.

Antoniou, Antonios, Yilmaz Guney, and Krishna Paudyal 2008. The Determinants of Capital Structure: Capital Market-Oriented Versus Bank-Oriented Institutions. Journal of Financial and Quantitative Analysis 43(1): 59-92.

Atanasova, Christina V. and Nicholas Wilson. 2003. Bank Borrowing Constraints and the Demand for the Trade Credit: Evidence from Panel Data. Managerial and Decision Economics 24(6-7): 503-514.

Atanasova, Christina V. and Nicholas Wilson. 2004. Disequilibrium in the UK Corporate Loan Market. Journal of Banking and Finance 28(3): 595-614.

Bae, Kee-Hong, Jun-Koo Kang , and Chan-Woo Lim. 2002. The Value of Durable Bank Relationships: Evidence from Korean Banking Shocks. Journal of Financial Economics 64(2): 181-214.

Barclay, Michael J., and Clifford W. Smith 1995. The Maturity Structure of Corporate Debt. The Journal of Finance 50(2): 609-631.

Beattie, Vivien, Alan Goodacre, and Sarah J. Thomson. 2006. Corporate Financing Decisions: UK Survey Evidence. Journal of Business Finance \& Accounting 33(9): 1402-1434.

Berger, Allen N., Nathan H. Miller, Mitchell A. Petersen , Raghuram G. Rajan and Jeremy C. Stein. 2005. Does Function Follow Organizational Form? Evidence from the Lending Practises of Large and Small Banks. Journal of Financial Econmoics 76(2): 237-269.

Bernanke, Ben, Mark Gertler and Simon Gilchrist. 1996. The Financial Accelerator and the Flight to Quality. The Review of Economics and Statistics 78(1):1-15. 
Bharath, S. T., Pasquariello, P., and Wu, G., 2009. Department of FinaDoes Asymmetric Information Drive Capital Structure Decisions? The Review of Financial Studies, 22, 3211-3243.

Biais, Bruno and Christian Gollier. 1997. Trade Credit and Credit Rationing. The Review of Financial Studies 10(4): 903-937.

Blinder, Alan S. and Joseph E. Stiglitz. 1983. Money, Credit Constraints, and Economic Activity, The American Economic Review 73(2): 297-302.

Boot, Arnoud W.A. and Anjan V. Thakor. 1994. Moral Hazard and Secured Lending in an Infinitely Repeated Credit Market Game. International Economic Review 35(4): 899920.

Bougheas, Spiros, Paul Mizen, and Cihan Yalcin. 2006. Access to External Finance: Theory and Evidence on the Impact of Monetary Policy and Firm-specific Characteristics, Journal of Banking and Finance 30(1):199-227.

Brav, Omer. 2009. Access to Capital, Capital Structure, and the Funding of the Firm. The Journal of Finance 64(1): 263-308.

Brozoza-Brzezing, Michal and Krzysztof Makarski. 2011. Credit Crunh in a Small Open Economy. Journal of International Money and Finance 30(7):1406-1428.

Bruno, Oliver. 2009. Credit Availability and Capital Crunch: On the Role of the Heterogeneity of the Banking System. Journal of Public Economic Theory 11(2): 251-279.

Burrell, G. and Morgan, G., 1979. Sociological Paradigms and Organizational Analysis, Hants, England: Gower Publishing Company Limited.

Campello, Murillo, Erasmo Giambona, John R. Graham, and Campbell, R. Harvery. 2011. Liquidty Management and Corporate Investment During a Financial Crisis. The Review of Financial Studies 24(6): 1944-1979.

Campello, Murillo, Erasmo Giambona, John R. Graham and Campbell R. Harvey. 2012. Access to Liquidity and Corporate Investment in Europe During the Financial Crisis. Review of Finance 16(1): 323-346.

Campello, Murillo, John R. Graham, and Campbell R. Harvey. 2010. The Real Effects of Financial Constraints: Evidence from a Financial Crisis. Journal of Financial Economics 97(3): 470-487.

Carey, Mark, Anil Kashyap, Raghuram Rajan, and René M. Stulz. 2012. Market Insitutions, Financial Market Risks, and the Financial Crisis. Journal of Financial Economics104(3): 421-424.

Cevik, Emrah. I. Sel Dibooglu, and Turalay Kenc. 2016. Financial stress and economic activity in some emerging Asian economies. Research in International Business and Finance 36, 127-139.

Chava, Sudheer and Amiyatosh Purnanandam. 2011. The Effect of Banking Crisis on Bankdependent Borrowers. Journal of Financial Economics 99(1):116-135.

Chen, Jing. 2004. Credit Distortion and Financial Crisis. International Review of Financial Analysis 13(1): 559-570.

Choi, Darwin, Mila Getmansky, Brian Henderson, and Heather Tookes. 2010. Convertible Bond Arbitrageurs as Suppliers of Capital. The Review of Financial Studies 23(6): 2492-2522.

Clarke, George R.G., Robert Cull and Gregory Kisunko. 2012. External Finance and Firm Survival in the Aftermath of the Crisis: Evidence from Eastern Europe and Central Asia. Journal of Comparative Economics 40(1): 372-392.

Colombo, Emilio. 2001. Determinants of Corporate Capital Structure: Evidence from Hungarian Firms. Applied Economics 33(13): 1689-1701. 
Cull, Robert, Maria Soledad Martinez Peria. 2013. Bank Ownership During the 2008-2009 Financial Crisis: Evidence from Latin America and eastern Europe. Journal of Banking and Finance 137(12): 4861-4878.

Dahya, Jay and Nickolaos G. Travlos. 2000. Does the One Man Show Pay? Theory and Evidence on the Dual CEO Revisited. European Financial Management 6(1): 85-98.

Deesomsak, Rataporn, Krishna Paudyal and Gioia Pescetto. 2004. The Determinants of Capital Structure: Evidence from the Asia Pacific Region. Journal of Multinational Financial Management 14(4-5): 387-405.

Denis, David J. 2011. Financial Flexibility and Corporate Liquidity. Journal of Corporate Finance, 17(3), 667-674.

Downward, P., 2016. Applied Economics and the Critical Realist Critique. Routledge, Taylor and Francis Group.

Duchin, Ran, Oguzhan Ozbas and Berk A. Sensoy. 2010. Costly External Finance, Corporate Investment and the Subprime Mortgage Credit Crisis. Journal of Financial Economics 97(3): 418-435.

Fattouh, Bassam, Pasquale Scaramozzino, and Laurence Harris. 2005. Capital Structure in South Korea: A Quantile Regression Approach. Journal of Development Economics 76(1): 231-250.

Flannery, Mark, Simon H. Kwan, and Mahendrarajah Nimalendran. 2013.The 2007-2009 Financial Crisis and Bank Opaquness. Journal of Financial Intermediation 22(1): 5584.

Forsberg, Richard H. 2012. Capital Structure and the Financial Crisis. Journal of Finance \& Accountancy 11(1): 469-480.

Franks, Julian R. , Kjell G. Nyborg and Walter N.Torous. 1996. A Comparison of US, UK, and German Insolvency Codes. Financial Management (Autumn) 25(3): 86-101.

Franks, Murray Z. and Vidhan K. Goyal. 2003. Testing the Pecking Order Theory of Capital Structure. Journal of Financial Economics 67(2): 217-248.

Gambacota, Leonardo and David Marques-Ibanez. 2011. The Bank Lending Channel: Lessons from the Crisis. Economic Policy 26(1): 135-182.

Gan, Jie. 2007. The Real Effects of Asset Market Bubbles: Loan- and Firm-level Evidence of a Lending Channel. The Review of Financial Studies 20(6): 1941-1973.

Garlappi. Lorrnzo and Hong Yan. 2011. Financial Distress and the Cross- section of Equity Returns. The Journal of Finance, 66(3): 789-822.

Gatchev, V.A., Spindt, P.A. and Tarhan, V., 2009. How Do Firms Finance Their Investments? The Relative Importance of Equity Issuance and Debt Contracting Costs. Journal of Corporate Finance 15, 179-195.

Ge, Ying and Jiaping Qiu. 2007. Financial Development, Bank Discrimination and Trade Credit. Journal of Banking \& Finance 31(2): 513-530

Gertler, Mark and Simon Gilchrist. 1993. The Role of Credit Market Imperfections in the Monetary Transmission Mechanism: Arguments and Evidence. The Scandinavian Journal of Economics 95(1): 43-64.

Gertler, Mark and Simon Gilchrist. 1994. Monetary Policy, Business Cycles, and the Behavior of Small Manufacturing Firms. The Quarterly Journal of Economics 109(2): 309-340.

Graham, John R. and Campbell R. Harvey. 2001. The Theory and Practice of Corporate Finance: Evidence from the Field. Journal of Financial Economics 60(2-3): 187-243.

Hall, Maximilian J. B. 2008. The Sub-prime Crisis, the Credit Squeeze and Northern Rock: The Lessons to Be Learned. Journal of Financial Regulation and Compliance 16(1): 19-34. 
Hall, Maximilian J. B. 2009. The Sub-prime Crisis, the Credit Crunch and Bank "Failure" an Assessment of the UK Authorities Response. Journal of Financial Regulation and Compliance 17(4): 427-452.

Hausman, J. A. 1978. Specification Tests in Econometrics. Econometrica 46(6): 1251-1271.

Holmstrom, Bengt and Jean Tirole.1997. Financial Intermediation, Loanable Funds, and the Real Sector. The Quarterly Journal of Economics 112(3): 663-691.

Ivashina, Victoria and David Scharfstein. 2010. Bank Lending during the Financial Crisis of 2008. Journal of Financial Economics 97(3): 319-338.

Jensen, M.C., 1986. Agency Costs of Free Cash Flow, Corporate Finance, and Takeovers. The American Economic Review. 76(2), 323-329.

Jeon, Yongil and Stephen M. Miller. 2004. The effect of the Asian Financial Crisis on the Performance of Korean Nationwide Banks. Applied Financial Economics 14(5):351360.

Jensen, M.C. and Meckling, W.H. 1976. Theory of the Firm: Managerial Behavior, Agency Costs and Ownership Structure. Journal of Financial Economics, 3(4), 305-360.

Jiang, Junhua. 2017. Discount rate or cash flow contagion? Evidence from the recent financial crises. Research in International Business and Finance. 39, 315-326.

Jones, Jeffrey S., Wayne Y. Lee, and Timothy J. Yeager. 2012. Opaque Banks, Price Discovery, and Financial Instability. Journal of Financial Intermediation 21(3): 383408.

Jordan, Judith, Julian Lowe, and Peter Taylor. 1998. Strategy and Financial Policy in UK Small Firms. Journal of Business Finance \& Accounting 25(1-2): 1-27.

Judge, Amrit and Anna Korzhenitskaya. 2012. Credit Market Conditions and the Impact of Access to the Public Debt Market on Corporate Leverage. International Review of Financial Analysis 25(1): 28-63.

Kahle, Kathleen M. and René M. Stutz. 2013. Access to Capital, Investment and the Financial Crisis. Journal of Financial Economics 110(2): 280-299.

Kashyap, Anil K. and Jeremy C. Stein .2000. What Do a Million Observation on Banks Say about the Transmission of Monetary Policy? American Economic Review 90(3): 407428.

Kashyap, Anil K., Owen A. Lamont, and Jeremy C. Stein. 1994. Credit Conditions and the Cyclical Behavior of Inventories. The Quarterly Journal of Economics 109(3): 565592.

Kohler, Marion, Erik Britton, and Tony Yates. 2000. Trade Credit and the Monetary Transmission Mechanism, Bank of England Discussion Paper.

Krishnan, V. Sivarama and R. Charles Moyer. 1997. Performance, Capital Structure and Home Country: An Analysis of Asian Corporations. Global Finance Journal 8(1): 129-143.

Lagoarde-Segot, T., 2016. Prolegomena to an alternative study of finance. in Bernard Paranque, Roland Pérez (ed.) Finance Reconsidered: New Perspectives for a Responsible and Sustainable Finance (Critical Studies on Corporate Responsibility, Governance and Sustainability, Volume 10) Emerald Group Publishing Limited, pp. 89-110.

Lang, William W. and Leonard I. Nakamura. 1995. Flight to Quality' in Banking and Economic Activity. Journal of Monetary Economics 36(1): 145-164.

Lawson, T., 2009. The current economic crisis: its nature and the course of academic economics. Cambridge Journal of Economics 33, 759-777.

Leary, Mark T. 2009. Bank Loan Supply, Lender Choice, and Corporate Capital Structure. The Journal of Finance 64(3): 1143-1185. 
Lemmon, Michael and Michael R. Roberts. 2010. The Response of Corporate Financing and Investment to Changes in the Supply of Credit. Journal of Financial and quantitative analysis 45(3): 555-587.

Lin, Huidan and Daniel Paravisini. 2013. The Effect of Financing Constraints on Risk. Review of Finance 17(1): 229-259.

Love, Inessa, Lorenzo A. Preve, and Virginia Sarria-Allende. 2007. Trade Credit and Bank Credit: Evidence from Recent Financial Crises. Journal of Financial Economics, 83(2): 453-469.

Majid, M. Shabri and Salina Hj Kassim. 2009. Impact of the 2007 US Financial Crisis on the Emerging Equity Markets. International Journal of Emerging Markets 4(4): 341-357.

Mac an Bhaird, Ciaran. 2013. Demand for debt and equity before and after the financial crisis. Research in International Business and Finance, 28, 105-117.

Mala, Rajni and Parmod Chand. 2012. Effect of the Global Financial Crisis on Accounting Convergence. Journal of Accounting and Finance 52(1): 21-46.

Mateut, Simona, Spiros Bougheas, and Paul Mizen. 2006. Trade Credit, Bank Lending and Monetary Policy Transmission. European Economic Review 50(3): 603-629.

Melvin, Michael and Mark P. Taylor. 2009. The Global Financial Crisis: Causes, Threats and Opportunities: Introduction and Overview. Journal of Inernational Money and Finance, 28(8): 1243-1245.

Mian, Atif and Amir Sufi. 2009. The Consequences of Mortgage Credit Expansion: Evidence from the U.S. Mortgage Default Crisis. The Quarterly Journal of Economics 124(4): 1449-1496.

Michaelas, Nicos, Francis Chittenden, and Panikkos Poutziouris. 1999. Financial Policy and Capital Structure Choice in U.K. SMEs: Empirical Evidence from Company Panel Data. Small Business Economics 12(2): 113-130.

Miller, M.H., 1977. Debt and Taxes. The Journal of Finance, 32(2), 261-275.

Modigliani, Franco and Merton H. Miller, 1958.The Cost of Capital, Corporation Finance and the Theory of Investment. The American Economic Review 48(3): 261-297.

Modigliani, F. and Miller, M. H., 1963. Corporate Income Taxes and the Cost of Capital: A Correction. The American Economic Review, 53(3), 433-443.

Murfin, Justin . 2012. The Supply- side Determinants of Loan Contract Strictness. The Journal of Finance 67(5): 1565-1601.

Myers, S.C., 1984. The Capital Structure Puzzle, The Journal of Finance, 39(3), 575-592.

Myers, Stewart C. 2001. Capial structure. The Journal of Economic Perspectives 15(2): 81102.

Myers, S.C. and Majluf, N.S., 1984. Corporate Financing and Investment Decisions When Firms have Information that Investors Do Not Have. Journal of Financial Economics, 13(2), 187-221.

Nilsen, Jeffrey H. 2002. Trade Credit and the Bank Lending Channel. Journal of Money, Credit and Banking 34(1): 226-253.

Obstfeld, Maurice. 2012. Financial Flows, Financial Crises, and Global Imbalances. Journal of International Money and Finance 31: 469-480.

Oliner, Stephen D. and Glenn D. Rudebusch. 1995. Is There a Bank Lending Channel for Monetary Policy?. Economic Review Federal Reserve Bank of San Francisco 2(1): 220.

Oliner, Stephen D. and Glenn D. Rudebusch. 1996. Monetary Policy and Credit Conditions: Evidence from the Composition of External Finance: Comment. The American Economic Review 86(1): 300-309. 
Ozkan, Aydin. 2001. Determinants of Capital Structure and Adjustment to Long Run Target: Evidence from UK Company Panel Data. Journal of Business Finance \& Accounting 28(1-2): 175-198.

Panno, A. 2003. An Empirical Investigation on the Determinants of Capital Structure: the UK and Italian Experience. Applied Financial Economics 13(2): 97-112.

Petersen, Mitchell A. and Raghuram G. Rajan. 1997. Trade Credit: Theories and Evidence. The Review of Financial Studies 10(3): 661-691.

Puri, Manju, Jorg Rocholl, and Sascha Steffen. .2011. Global Retail Lending in the Aftermath of the US Financial Crisis: Distinguishing between Supply and Demand Effects. Journal of Financial Economics 100(3): 556-578.

Rajan, Raghuram G. and Luigi Zingales. 1995. What Do We Know about Capital Structure? Some Evidence from International Data. The Journal of Finance 50(5): 1421-1460.

Reinhart, Carmen M. and Kenneth S. Rogoff. 2011. From Financial Crash to Debt Crisis. American Economic Review 101(5): 1676-1706.

Ross, S.A., 1977. The Determination of Financial Structure: The Incentive-Signalling Approach. The Bell Journal of Economics, 8(1), 23-40.

Saretto, Alessio and Heather E. Tookes. 2013. Corporate Leverage, Debt Maturity, and Credit Supply: the Role of Credit Default Swaps. The Review of Financial Studies 26(5): 1190-1247.

Stein, Jeremy C. 2003. Agency, Information and Corporate Invesment. Handbook of the Economics of Finance, 1: 111-165.

Saleem, Kashif. 2009. International linkage of the Russian market and the Russian financial crisis: A multivariate GARCH analysis. Research in International Business and Finance 23, 243-256.

Sufi, Amir. 2009. The Real Effects of Debt Certification: Evidence from the Introduction of Bank Loan Ratings. The Review of Financial Studies 22(4): 1659-1691.

Titman, Sheridan and Roberto Wessels. 1988. The Determinants of Capital Structure Choice. The Journal of Finance 43(1): 1-19.

Voutsinas, Konstantinos and Richard A. Werner. 2011. Credit Supply and Corporate Capital Structure: Evidence from Japan. International Review of Financial Analysis 20 (5): 320-334.

White, Halbert. 1980. A Heteroskedasticity-Consistent Covariance Matrix Estimator and a Direct Test for Heteroskedasticity. Econometrica 48 (4): 817-838.

Yang, Xiaolou. 2011. Trade Credit versus Bank Credit: Evidence from Corporate Inventory Financing. The Quartely Review of Economics and Finance, 51(4): 419-434.

Yarovaya, Larisa, and Marco C. K. Lau. 2016. Stock market co movements around the Global Financial Crisis: Evidence from the UK, BRICS and MIST markets. Research in International Business and Finance 37, 605-619. 